\title{
15. Facework and identity
}

\author{
Miriam A. Locher and Brook Bolander
}

\begin{abstract}
This chapter reviews studies which focus on Internet users' attempts to change (challenge, reinforce, negotiate) current or past, stereotypical, individual and/or group identities in interactions. It thereby acknowledges that the literature regularly draws on various theoretical conceptions of identity. Perspectives on identity range from sociolinguistic understandings of the impact of social variables on linguistic variation to constructivist and discursive negotiations of identity as employed in conversation analysis, discourse analysis and discursive psychology. These latter approaches share a particular view of identity as a complex, emergent, context-sensitive, social, ephemeral/changing and negotiable concept. Methodologies vary according to theoretical orientation so that we find a rich mixture of quantitative and qualitative studies. In addition to addressing these different conceptualisations of and approaches to identity, the chapter also reviews a number of key themes which emerge in the literature review: the importance of (im)politeness; the impact and negotiation of gender; the construction of expertise, authenticity and trust; the surfacing of emotions; the creation of in- and out-groups and community building; and the intertwining of offline and online acts of positioning.
\end{abstract}

\section{Introduction}

It has been long established that language contains a relationship component and that any act of communication thus implicitly and often also explicitly says something about the relationship of the interactants involved (e.g. Watzlawick, Beavin and Jackson 1967). The same pertains to computer-meditated communication (CMC), such that research on CMC also lends itself to studies on identity and relationship construction. A famed cartoon by Peter Steiner (1993) in The New Yorker depicts two dogs in front of a computer, one of which had been typing and then informs the other that "on the Internet, nobody knows you're a dog". Ever since this cartoon, it is not just scholars but also lay people who have been aware of the fact that the keyboard can be used to write oneself into being (Sundén 2003). While the quotation highlights the anonymity that online interaction can grant its users, more recent social media practices show that users also reveal their name, post pictures and videos of themselves, and write texts (for example status updates) to show their worldviews. They thus share a considerable amount of information about themselves. This is not to deny that anonymous and/or creative identity construction can still take place, but with the advent of web 2.0 platforms,

In: C. R. Hoffmann and W. Bublitz (eds.). (2017). Pragmatics of Social Media, 407-434. Berlin/Boston: De Gruyter Mouton. 
the spectrum of different acts of positioning is even wider than before. Complex acts of positioning which create affiliations and disaffiliations result in creative practices of online identity construction.

This chapter first touches on a number of linguistic theories that discuss identity construction and its link to facework (Section 2). It then offers a succinct review of recurrent themes in identity construction research dealing with online data (Section 3). The chapter then moves to a presentation of a number of studies in recent social media practices, such as Facebook and Twitter (Section 4), before concluding in Section 5.

\section{Theories of identity construction}

Within linguistics, the topic of identity construction has a long tradition and it is defined and approached in many different ways. The study of how interactants use language to shape their persona or image has been of concern within many subfields, among them pragmatics, sociolinguistics, discourse analysis, conversation analysis, anthropological linguistics and literary pragmatics. Linguistics has benefitted much from insights from other disciplines, among them rhetorics, gender studies, sociology, anthropology, literary studies and discursive psychology, which focus on language as well as other forms of communication. Depending on how widely or how narrowly one defines identity, the above-mentioned disciplines and fields can be drawn on for our respective research questions and methodological decisions.

Rhetorics, for example, has shown us that politicians who want to persuade others in order to be elected or to convince people of their ideas, try to appear knowledgeable but not scholarly, friendly and approachable but not chummy, etc., depending on their target audience and cultural context (see, e.g., Burke 1969 on the use of pathos, ethos and logos). The study of how persuasion is performed and power exercised is also of concern for linguists working on CMC, such as public health sites or political campaign sites (see Section 3.3 below).

From sociolinguistics in the Labovian (1972) tradition, we learn that the ways in which speakers utter words and choose lexemes reveal something about their class, ethnicity, age and/or gender. Individuals may also aspire to sound like a member of a higher social class (see, e.g., the phenomena of hypercorrection and overt prestige) or adhere to their sociolect in order to distance themselves from other groups and create ingroup solidarity (covert prestige; see, e.g., Labov 1972; Meyerhoff 2006). Identity in these studies is functionalized through the inclusion of social variables into the research design. As a consequence, identity is depicted with a broad brush that considers the values of gender, class, age and ethnicity as methodologically given.

Studies that use insights from linguistic anthropology, ethnology, and conversation analysis provide further important findings with respect to the indexical 
power of language. These lines of investigation target a more fine-grained picture of identity since the focus is on the construction of identity in interaction. For example, Irvine (2001) studies in minute detail how language indexes social belonging in a Wolof village in Senegal and reports on Gal's (1992) work on the Hungarian village Bóly where cultural and ethnic belonging is indexed through linguistic style. And Ochs (1993: 288) demonstrates how "speakers attempt to establish the social identities of themselves and others through verbally performing certain social acts and verbally displaying certain stances" (emphasis in original). The concept of membership categorization developed in conversation analysis (see, e.g., Sacks 1992; Antaki and Widdicombe 1998; Hester and Eglin 1997; Fitzgerald 2015) helps to show the practices through which interactants themselves draw on lexemes for self-identification (such as mother, sister, daughter) and style in order to highlight those aspects of their identities that they wish to make salient in interaction.

The constructivist stance is also key in Eckert (1989) and Mendoza-Denton (2008), who demonstrate how students use linguistic and other practices to index ingroup and outgroup belonging. The latter work creatively combines quantitative aspects from variationist sociolinguistics with qualitative observations about the indexicality of linguistic markers. Furthermore, the study of identity construction is expanded beyond a focus on language use to include other practices like afterschool activities, hairstyle, and clothing.

Research on stylistics and the pragmatics of fiction highlights that language is a crucial means to create characters in fictional worlds. The authors' and actors' choices for register, accent and syntax tap into the readers' and viewers' world knowledge in that they evoke stereotypes, which act as recognizable cues for the readers/audience. ${ }^{1}$

From discursive psychology, we get the concept of positioning (Davies and Harré 1990; Bamberg 1997; Deppermann 2013), which contributes to a better understanding of how people create storylines for themselves in face-to-face interactions, therapy and storytelling. This tradition complements the sociologist Goffman's $(1955,1959,1967,1974)$ metaphor of the stage ${ }^{2}$ and the idea that people take on and enact (dynamic) different roles in particular situations. Positioning theory has also influenced Bucholtz and Hall's work (2005, 2008, 2010; Hall and Bucholtz 2013), which further demonstrates the interdisciplinarity of this research field. They explore "the social positioning of self and other" (Bucholtz and Hall

1 Here, the reader is referred to the handbook Pragmatics of Fiction (Locher and Jucker 2017), which reviews crucial linguistic strategies for characterization, among them regional, social and ethnic linguistic cues, stance markers and code-switching.

2 In Goffman's “dramaturgical approach" (Willems 2001: 6298) the metaphors of theatre and the stage are used to point to "the manipulative and the moral aspects of social life" (Léon 2006: 98). 
2005: 586), and posit that there are five principles which show the complexity of identity construction. These principles highlight that identity is a relational phenomenon (relationality principle), which emerges in interaction (emergence principle), and which is indexed (indexicality principle) through processes of positioning through which interactants attempt to position self and other (positionality principle). By studying such acts we only ever get a partial glimpse of identity construction (partialness principle), which can be complemented (contradicted, challenged, reconfirmed) in previous and following interactions and which is influenced by competing (cultural) discourses (e.g. on gender and roles).

The concept of face is also important to (im)politeness research (and interpersonal pragmatics more generally; see Locher and Graham 2010). This field of research is concerned with relationship creation through interaction and it thus studies how face is negotiated and how facework patterns in different situations and cultural contexts. Here Goffman $(1955,1967)$ is again important, since his concept of face and facework are crucially interlaced with (im)politeness studies. To be judged a polite or well-mannered person might be a motivation for choosing between different possibilities of performing a speech act. The ways we use language thus say something about our understanding of the social situation we find ourselves in and how we judge our relationship towards others (see also Section 3.1).

While research on facework overlaps with politeness research (and might be considered synonymous by some researchers), there are scholars who work with the concept of face without necessarily studying politeness norms. For example, the concepts of rapport management (Spencer-Oatey 2007), relational work (Locher and Watts 2005) and face-constituting theory (Arundale 2015) all draw on the notion of face ${ }^{3}$ but do not necessarily or exclusively study (im)politeness concerns. These concepts are thus more encompassing than (im)politeness. Yet they can all be tied to identity management and relationship creation (see Locher 2008 for this link).

The field of gender studies, itself interdisciplinary in nature, also illustrates the different approaches to the study of identity. There are numerous overview articles (e.g. Mullany 2012; Sunderland and Litosseliti 2002; Swann 2002) that trace the development from a more essentialist to a more constructivist approach and that highlight that a gender identity may be one of many identity traits that might be made salient by interactants in situ. Studying the impact of gender on CMC will be taken up in Section 3.2.

The metaphor of face itself has been discussed extensively and its definitions vary from assigning it the status of universal psychological wants (e.g. Brown and Levinson 1987 ) to more negotiable understandings (e.g. Goffman 1955). It is beyond the scope of this chapter to give a history of this concept (but cf. Section 3.1). For an overview, the reader is referred to Bargiela-Chiappini (2006). 
This chapter cannot do justice to all of these different traditions of studying identity construction, nor to all of the concepts that are associated with this process (see, e.g., style, stance, indexicality, stereotype, (im)politeness). For overviews on research on identity, see, among others, De Fina (2010), Joseph $(2004,2010)$, Kiesling (2006), Locher (2008) and Mendoza-Denton (2002). What is central here is recognising the diversity of approaches, since this same diversity is mirrored in studies that explore identity construction in computer-mediated contexts and social media in particular. For example, we find qualitative case studies conducted in an ethnomethodological, conversation analytic or discourse analytic tradition, as well as large-scale quantitative studies of linguistic expression where data is separated according to social variables. Much of the research we review in Sections 3 and 4 also alludes to (im)politeness theories as identity construction goes hand in hand with (im)politeness considerations (for observations on this interface, see Locher 2008; Hall and Bucholtz 2013).

\section{Themes in identity construction research on online data}

Reviewing the literature on identity construction in online data, we first need to reiterate that any form of language use contains elements of recipient/audience design and thus represents a choice of a particular interactant as to available linguistic variants. This means that any type of CMC can be studied from what Locher and Graham (2010: 1) call an interpersonal pragmatics perspective, i.e. with respect to its relational component. Relational work, i.e. the communicative choices interactants make and how these are interpreted in light of relationship creation (e.g. address terms, register, levels of mitigation, Locher and Watts 2005), then leads to identity construction. Social network sites such as Facebook might be immediately associated with relationship maintenance and creation since this is also the declared aim of the platform. Yet we wish to stress that it is not only such social network sites that lend themselves to the study of identity construction. Nor does interactivity have to be built into the technical make-up of the practice as in discussion boards or newspaper comments sections. Also less obviously social or interactive online practices such as information websites can be explored with respect to identity construction via a focus on concepts such as stance, style or positioning.

In the following we introduce a series of pertinent themes for the study of identity construction online: the importance of (im)politeness; the impact and negotiation of gender; the construction of expertise, authenticity and trust; the surfacing of emotions; the creation of in- and out-groups and community building; and the intertwining of offline and online acts of positioning. In light of our conviction that identity construction can be performed in various modes, these themes do not stem from studies on just one type of online interaction but from a mixture of sources. 
In turn, insights from the studies may feed into more than one theme, such that individual studies may be relevant with respect to a series of the identified themes.

\section{1. (Im)politeness: From face-enhancing to face-aggravating behavior}

Studying concerns about politeness and impoliteness is an important theme in linguistic research on online communication (see also Graham, Ch. 17, this volume). The link to identity construction hinges around the concept of face and facework (see Goffman 1955, 1967; Bediijs, Held and Maaß 2014b). Face is defined by Goffman (1967: 5), as "the positive social value a person effectively claims for himself [sic] by the line others assume he has taken during a particular contact". Considering someone's face in interaction means that speakers engage in facework and project identities that might challenge, confirm or negotiate roles that surface as relevant in a particular interaction. Since communication online is not faceless in its metaphorical sense, we can assume that facework is equally important as it is in face-to-face communication (see also the discussion in Bediijs, Held and Maaß 2014b and Held 2014).

In many ways what happens in this research field mirrors general trends in (im)politeness research. These include discussions on methodological and theoretical concerns such as the role of universality within a given framework or the distinction between emic and etic approaches; broadening the scope of data and interest, which now also includes impoliteness and aggression; the role of emotions; the emergence and negotiation of norms; processes of judging and historical developments of modes of conduct in given societies (for overviews on developments in this field, see Locher 2013a, 2014, 2015). Given this wide field of interest covered by (im)politeness research nowadays, it comes as no surprise that we find many studies on CMC and (im)politeness, but no unified theoretical or methodological approach.

The literature review shows that there are several reasons why (im)politeness scholars have been particularly motivated to research computer-mediated language. These reasons are often intertwined and thus not mutually exclusive:

- To further theory building: The last two decades have seen an upsurge in theoretical discussions about how to approach the study of (im)politeness phenomena. The new data available from computer-mediated contexts was readily utilised as testing grounds for established and new ideas. Brown and Levinson's (1987) key concepts of face (adopted and developed from Goffman 1955) as well as face-threatening act (FTA), and their taxonomy of mitigating the force of FTAs (from bold on record, with mitigation, to off record) is also applied to online data, at times in adapted forms (e.g. Bou-Franch and Garcés-Conejos Blitvich 2014; Kleinke and Bös 2015; Herring 1994; Neurauter-Kessels 2011, 2013; Yus 2011). At the same time, scholars also employ more recent discur- 
sive understandings of politeness and particularly focus on local and situated emergent forms of (im)politeness (e.g. Angouri and Tseliga 2010; Graham 2008; Haugh 2010; Locher 2008; Planchenault 2010).

- To study emic negotiations of norms of conduct in and about computer-mediated communication: As interactants adopt new forms of CMC, new norms of conduct are explicitly commented on and addressed. As a result, we find many practices where meta-discussions on appropriate or inadequate behavior are negotiated. This is the case with respect to forms of Netiquette that were published and discussed (e.g. for email conduct and behavior on message boards). In addition, there are many threads in discussion boards or online articles where interactants comment on offline codes of conduct. This data is thus rich for scholars who are interested in the negotiation of norms on personal, local or societal levels and who focus on meta-pragmatic comments. Representative examples of such studies are Arendholz (2013, 2014), Graham (2007, 2008), Haugh (2010), Haugh, Chang and Kádár (2015) and Locher (2008).

- To explore face-aggravating behavior: Scholars interested in developing politeness theories which can also deal with impoliteness and aggressive face behavior found rich data of conflictual and face-aggravating behavior in computer-mediated contexts. While recording aggression and conflict in face-to-face contexts might often be a matter of chance, online data seems to give easy access to such data (for ethics and other research challenges, see Bolander and Locher 2014). Numerous studies focus especially on face-aggravating data and explore it with (im)politeness theories (e.g. Arendholz 2013, 2014; Kunkel 2014; Neurauter-Kessels 2011, 2013; Langlotz and Locher 2012). In early research on online communication, the possibility for anonymous posting was seen as an uninhibiting factor that resulted in less mitigation, directness and bluntness (Baym 1996; Reid 1999). In addition, practices such as trolling, flaming and shaming and the ensuing discussion about appropriate behavior received attention (e.g. Arendholz 2013; Hardaker 2010; Helfrich 2014; Kluge 2014; Perelmutter 2013, 2015; Rentel 2014; Turnage 2007). While not every study on face-aggravating behavior in a computer-mediated context necessarily draws on (im)politeness theories, the general link to identity construction and facework is usually a given. For a review of studies on consensual and conflictual disagreement in online contexts, see Bolander and Locher (Ch. 22, this volume).

The overview of (im)politeness studies on computer-mediated data draws a rich picture of interpersonal strategies that can be used for face-maintenance, face-enhancing and face-aggravation. Screening the texts with respect to epistemology and methodology, it becomes apparent that we find studies adopting a constructivist understanding of politeness and identity; and a leaning toward qualitative 
explorations, although there are also quantitative and mixed-method approaches. Special journal issues and edited collections (Bedijs, Held and Maß 2014a; Locher 2010; Locher, Bolander and Höhn 2015) particularly tackle the interface of identity construction, relational work and (im)politeness studies in CMC. A number of monographs highlight aspects of relational work in different computer-mediated contexts (e.g. Arendholz 2013; Dayter 2016; Locher 2006; Yus 2011) and recent papers and handbooks offer overviews of (im)politeness research and CMC (e.g. Dynel 2015; Hardaker and Graham 2017; Graham, Ch. 17, this volume).

The contexts studied vary, and include:

- blogs (e.g. Bolander 2012, 2013; Luzón 2013; Perelmutter 2013),

- chats (e.g. Linnemann, Brummernhenrich and Jucks 2014; Vandergriff 2013; van Compernolle, Williams and McCourt 2011),

- discussion boards and fora (e.g. Angouri and Tseliga 2010; Arendholz 2014; Ehrhardt 2014; Eisenchlas 2012; Fröhlich 2014; Haugh 2010; Haugh, Chang and Kádár 2015; Held 2014; Herring 1994; Kleinke and Bös 2015; Kreß 2014; Kunkel 2014; Maaß 2014; Nishimura 2010; Perelmutter 2015; Planchenault 2010; Placencia 2012; Schrader-Kniffki 2014; Shum and Lee 2013; Thaler 2014),

- email interaction (e.g. Darics 2010; Hössjer 2013),

- mailing lists (e.g. Graham 2007, 2008),

- newspaper comments (e.g. Upadhyay 2010; Langlotz and Locher 2012; Neurauter-Kessels 2011, 2013),

- Youtube videos and comments and other polylogues (e.g. Bedijs 2014; BouFranch and Garcés-Conejos Blitvich 2014; Dayter and Rüdiger 2014; Lange 2014; Placencia 2012),

- social network sites (see Section 4 in this chapter, and Eisenlauer, Ch. 9, this volume),

- and text messaging (Spilioti 2011; Georgakopoulou 2013).

\subsection{Gender}

As mentioned in Section 2, studies on gender and identity construction have a long tradition, which has been continued with data from many different computer-mediated contexts (for overviews, see, e.g., Herring 2003; Herring and Stoerger 2014). In their recent review article, Herring and Stoerger (2014: 567) explore the impact of anonymity on CMC in light of gender and the popular claim that $\mathrm{CMC}$ is "inherently democratic, leveling traditional distinctions". They report that online communication has erroneously been perceived as a context where gender can be neutralized or power differences made to disappear (Herring and Stoerger 2014: 578). The studies they review demonstrate that gender still becomes salient both with respect to access and use, and the distribution of textual or multimodal features. The picture, however, is diverse and context-sensitive. Thus, while men 
are typically seen as adopting a more aggressive communicative style compared with women, in the case of asynchronous discussion lists and forums, "Herring (1996 [...]) observed a majority-gender effect: women tend to be more aggressive in male-dominated groups than among other women, and men tend to be more aligned in female-dominated groups than in groups dominated by men" (Herring and Stoerger 2014: 570).

The results are also mixed with respect to language use, e.g., vocabulary, style and speech acts (Herring and Stoerger 2014: 572). From a discursive perspective this is not surprising, since gender ideologies are not expected to disappear in computer-mediated contexts, but are instead made salient in varying ways by interactants. As Page's (2012: 91) study of storytelling in various online, polylogue contexts confirms, "gender persists as a meaningful category in computer-mediated contexts and [...] offline values do not disappear in online interaction". And in a review on studies of texting, Thurlow and Poff (2013: 166) report that the fact "[t]hat gender differences emerge in young people's preferred communication styles is hardly surprising (Thurlow 2001); these findings do, however, reiterate the variability that exists between texters and the messages they send".

With respect to research methodologies employed in studies on gender in computer-mediated contexts, we find the same broad distinctions that also characterize the research on facework and identity construction in general. There are studies that are interested in exploring whether and how men and women use language differently by considering gender a social variable for exploring different computer-mediated contexts, often with a quantified study design (e.g. Chen and Abedin 2014; Herring and Paolillo 2006; Knupsky and Nagy-Nell 2011; Panyametheekul and Herring 2003). On the other end of the spectrum, we also find qualitative research on how individuals or groups of individuals negotiate gender. For example, Herring's (1999) two case studies from an Internet Relay Chat channel and a listserv discussion group show how men and women are treated differently when disagreeing. This results in what Herring (1999: 151) calls a "rhetoric of harassment" against women, which surfaces differently in the two online contexts: "Whereas female participants on IRC are kicked off the channel, in the discussion group harassers must rely exclusively on language to intimidate and silence". A further example is Lee's (2011) study of one woman who used status updates while giving birth (see also Section 4), or Perelmutter's (2015) work on how Russian women negotiate appropriate and inappropriate behavior on a forum dedicated to marital infidelity. By employing acts of shaming addressed to mistresses and wives, the interactants in Perelmutter's (2015) research make gender roles salient:

Since the overarching societal norms and expectations of family mores and gendered behavior in the post-Soviet society are often unclear, these shaming practices help Russian-speaking women construct and negotiate their identities within a group of peers. These negotiations integrate individual, group, and societal face concerns. (Perelmutter 2015: 149) 
There are also studies that combine quantitative with qualitative analysis and insights derived from different datasets (e.g. Eisenchlas 2012; Hampel 2015; Page 2012). Planchenault's $(2010,2015)$ study on how transvestites construct gender roles to position themselves in their online communities is a case in point. She reports how roles and experiences with roles are discussed on a meta-level and how gender markers in French are used in an intricate combination of acts of positioning: grammatical female endings visible in orthography in adjectives or past participles but not always pronounced are combined with the male and female form of nouns. This allows the posters to create ambiguity and to play with their identities on a lexical, grammatical level (Planchenault 2010: 93). Another example is Zhang and Kramarae's (2014: 66) work on online meta-discussions of gender norms in the context of Chinese online debates about "Shanghai Metro's official 'dress-code' warning to women passengers". The authors use a corpus of comments as reactions to the initial message posted by Shanghai Metro and complement this with further online sources and the response by Shanghai metro. They then explore the discursive strategies that the different players employ. This results in a very heterogeneous, often contradictory and at times ambiguous picture about how gender and feminism are negotiated online in present-day China.

\subsection{Expertise, authenticity and trust: Experts and laypeople} in e-health interaction

The negotiation of facework and the construction of identity is particularly salient in the field of professional and lay interaction, where expertise, authenticity and trust are at stake. This can be a concern for information outlets such as newspaper articles, governmental information websites, websites of political parties, e-campaigns and e-presence of political candidates and e-health communication. In this review, we focus on e-health practices.

In Locher and Schnurr's (2017) literature review on health and (im)politeness research, studying e-health practices is considered one of the up-and-coming themes. Within both interpersonal pragmatics in general, as well as for e-health in particular, four key concerns emerge:

- The face-threatening potential of many interactions in health contexts;

- The negotiation of roles pertaining to health interaction in dynamic encounters;

- The creation and maintaining of trust and expertise;

- The importance of advice giving, information giving, counselling, etc.

(Locher and Schnurr 2017: 698)

We thus find, for example, a number of studies which explore how interactants attempt to negotiate roles and identities in order to come across as credible experts (patients and health practitioners alike) in different online contexts. This includes research from both a linguistic and psychological perspective (among them, Harri- 
son and Barlow 2009; Harvey and Koteyko 2013; Hunt and Koteyko 2015; Koteyko and Hunt 2016; Locher 2006, 2013b; Locher and Hoffmann 2006; Rudolf von Rohr 2015; Sillence 2010, 2013; Thurnherr, Rudolf von Rohr and Locher 2016).

One example of this research conducted from a linguistic perspective is Locher's (2006; cf. also Locher and Hoffmann 2006) study of advice online in the American Internet advice column "Lucy Answers". Here, the professional advisor persona $L u c y$, who is created by a team of health professionals and presented as an agony aunt, distinguishes herself by, for example, providing up-to-date researched factual information on health concerns (e.g. by quoting statistics or referring to books and other sources), embedding her advice within other discursive moves to lower its face-threatening character, displaying a sense of humour, not being afraid to criticize and appearing approachable through her choice of vocabulary (while not being informal, there is a clear avoidance of medical jargon) (see Locher and Hoffmann 2006). The importance of embedding advice and thus mitigating it to a certain extent has also been reported for other online advice practices (e.g. Morrow 2006, 2012 and Ch. 24, this volume; Placencia 2012 and references in the next paragraph).

With respect to peer-to-peer interactions, we can refer to studies by Harrison and Barlow (2009), Harvey and Koteyko (2013), Hunt and Koteyko (2015), Kouper (2010), Koteyko and Hunt (2016), Rudolf von Rohr (2015), Sillence (2010, 2013) and Thurnherr, Rudolf von Rohr and Locher (2016), which all convincingly demonstrate that peers also engage in the creation of expertise and trust. For example, in a study of how peers help each other in their journey to quit smoking in an online forum, Rudolf von Rohr (2015: 264) observes that "[p]articipants who seek help have to convince other forum members of the authenticity of their claim, while helpers need to establish their expertise to give advice or emotional support". In other words, it is not just the self-selected advice-givers who engage in warranting strategies to demonstrate their expertise and thus legitimize their role, but also the advice-seekers, who need to establish their authentic identity as experts of their personal quitting situation, so that they are "considered help-worthy" (Harvey and Koteyko 2013: 165). To give another example of the intricate negotiation of roles in e-health practices, both Harrison and Barlow's (2009) research on a diabetes peer-to-peer forum and Thurnherr, Rudolf von Rohr and Locher's (2016) analysis of various online e-health sources show how sharing narratives can function as a resource for giving advice and creating a credible identity as a resource for help.

Research on e-health practices is still developing and to approach it with an interpersonal pragmatics lens, which is interested in identity construction and facework, proves promising in light of exploring the themes listed at the beginning of this section. The interest guiding this research can be both applied (e.g. health practitioners might benefit from insights on how expertise can be indexed linguistically) and theoretical (e.g. how do peers differ from experts in their use of strategies for imparting advice and sharing expertise, etc.). 


\subsection{Further themes}

A number of further themes will be mentioned in passing only. The first has to do with in-group and out-group creation and community building in general. This is connected to the negotiation of face and the construction of identity since acts of positioning employed to affiliate and disaffiliate oneself from others influence emerging identities. For example, many studies on conflict also discuss online community building and involve meta-discussions of group norms (e.g. Baker 2001; Baym 1996, 1998; Dayter 2016; DuVal Smith 1999; Reid 1999; references mentioned in Section 3.1 on face-aggravating behavior).

A further strand of research zooms in on the expression of emotions and how emotional stance cues add to identity construction, the negotiation of interpersonal relations and community building (e.g. Maíz-Arévalo and García-Gómez 2013; Langlotz and Locher 2012; Skovholt, Gronning and Kankaanranta 2014). For example, for their data of Taiwanese parenting fora, Haugh and Chang (2015: 99) report that emotional support can be expressed via both "affiliative responses" (including "mutual encouraging, mutual bemoaning, and empathic suggesting") and "dissafiliative responses" (including "accusing and advising"). These diverse possibilities of expression highlight the importance of "soliciting emotional support" as a relational practice in these discussion boards.

To give another example, in their research on emoticons in workplace emails, Skovholt, Gronning and Kankaanranta (2014: 780) underscore several functions of emoticons in workplace e-mails, which are not primarily used to index the writers' emotions, as one might at first glance expect. Instead, the emoticons function as "contextualization cues", which "provide information about how an utterance is supposed to be interpreted" (Skovholt, Gronning and Kankaanranta 2014: 780). More specifically, these include marking "a positive attitude" when they occur after signatures; functioning as markers of jokes or irony when they follow utterances intended as humorous; and serving as "strengtheners" after expressive speech acts and "softeners" after directives (Skovholt, Gronning and Kankaanranta 2014: 780). From a perspective that takes facework and identity construction into account, exploring emotional stance clearly promises more insights for the study of relational work.

As a final theme, we would like to mention studies that focus on the intricate interplay between online and offline activities of interactants with respect to identity construction (e.g. Georgakopoulou 2013; Lee 2011; Mak and Hin Leung Chui 2014). There are many studies on CMC where no background information is available on the participants or where studying interactants' offline communicative behavior would not be possible (e.g. polylogue chatrooms, fora, online games, etc.). There are, however, studies that focus on the individual and that thus follow $\mathrm{him} / \mathrm{her}$ in order to understand better how offline and online acts of communication intertwine. Georgakopoulou (2013), for example, accompanies young people 
during their school days and observes how acts of $\mathrm{CMC}$ and information shared in such acts (e.g. texting) also shape their face-to-face negotiation of identities and become part of the small stories that they share. And Lee (2011) shows how a Chinese women uses status updates to keep her friends informed about the progress of her birthing experience (see below). These studies are by nature qualitative.

\section{Examples from Facebook and Twitter}

To illustrate some of the findings previously discussed, this section reviews a selection of studies on identity construction on the social networking site (SNS) Facebook and the microblogging platform Twitter. SNS are "web-based services that allow individuals to (1) construct a public or semi-public profile within a bounded system, (2) articulate a list of other users ['friends'] with whom they share a connection, and (3) view and traverse their list of connections and those made by others within the system" (boyd and Ellison 2007). boyd and Ellison (2007) established the following sequence of appearance of SNS: MySpace in 2003; Flickr and Facebook (the Harvard-only version) in 2004; YouTube and Facebook (for high-school networks) in 2005; and Twitter and Facebook (for everyone) in 2006. SNS combine previously separate online ways of communication within one platform (e.g., posting status updates, sharing photographs and videos, reposting/sharing other users' material, chatting, commenting on each other's activities, playing games and participating in surveys; see, e.g. Herring 2013; Jucker and Dürscheid 2012; Locher 2014; Thurlow and Mroczek 2011). Characteristically, the technological affordances of these providers are constantly developing (see, e.g., Bolander 2017; Eisenlauer 2013 and Ch. 9, this volume; Locher 2014: 558). As a consequence, the literature on social media interaction always needs to state clearly how a particular practice worked at the time during which the data was recorded. This ensures transparency on whether the data is comparable, and prompts for reflection on the ways it might be more or less comparable given the change/s in question. It also encourages increased research on the diachronic development of Facebook practices over time. While such work is scant, Lee (2011) and Page (2012), for example, include analysis of the shift in 2009 in the status update prompt from "What are you doing right now?" to "what is on your mind"; and Koteyko and Hunt (2016) explore health identities on Facebook via a longitudinal (four-month long) observation of 20 Facebook profiles.

In our own research on identity construction in Facebook (inspired by Zhao, Grasmuck and Martin 2008), we focused on what people reveal in their profile pages and in status updates. Our choice to prioritise status updates over other activities performed by our interlocutors was based on them being the primary activity in our data collected from two groups of ten students (living in the UK and Switzerland) between December 2008 and January 2009 (Bolander and Locher 2010, 
2015; Locher and Bolander 2014, 2015; Locher 2014). Drawing on a previous study on away messages in Instant Messaging (Nastri, Peña and Hancock 2006), we analysed what the students write about on a speech act level and what acts of positioning are evoked within the status updates. We found that the two groups of students put different emphasis on identities related to personality, pastime endeavours, sense of humour, work and relationships, and that individuals draw on and position themselves with respect to these categories to differing degrees. In the reactions to status updates, we found a predominance of moves that confirm acts of positioning by the status updates writers and only a handful of challenges. However, many status updates received no comments at all. We also found that the ten individuals living in Switzerland draw on more language varieties when writing their status updates than the UK-based focus group, with multilingualism thus serving as a resource for identity construction.

While our choice of data (status updates) emerged from the nature of the Facebook platform at the time of analysis, working with current data warrants a more multi-modal approach that includes photographs, videos and memes and which captures interaction (reactions to interactional moves within the platform and also interaction between offline and online practices) (e.g. Bolander and Locher 2015; Dayter and Rüdiger 2014; Lee 2011; Locher and Bolander 2014, 2015; MaízArévalo 2013; Maíz-Arévalo and García-Gómez 2013; Mak and Hin Leung Chui 2014; Page 2012, 2014a; Peña and Brody 2014; Theodoropoulou 2015). In this vein, Lee (2011) focuses on a female user and author of status updates, who documents the process of giving birth and thus her transition into motherhood. This example highlights that the distinction between offline and online life is not tenable. In documenting the act of giving birth via Facebook in front of witnesses (Facebook "friends"), it also highlights a blurring of private and public (see also Jucker and Landert 2011; Landert 2014).

Our second example of a computer-mediated context is from the microblogging platform Twitter, which started in 2006 and provides its users the opportunity to post messages that are restricted to 140 characters. As Zappavinga (2012: 3) succinctly describes, these posts are addressed either to the "general internet" or a specific set of "followers" who have subscribed to an individual's "message stream"; the posts are subsequently displayed in reverse chronological sequence "as an unfolding stream of content". Research on identity construction on Twitter has been growing rapidly since the turn of the decade, with Zappavigna (2012, 2014a, 2014b), Page (2012, 2014a, 2014b), Dayter (2014, 2016) and Rentel (2014), for example, exploring tweets as instances of microblogging that - in their cumulative effect over time - add up to acts of identity construction.

Zappavigna (2012: 14) maintains that "people use Twitter and other microblogging services to share their experiences and enact relationships rather than to simply narrate the mundane details of their activities, as has been claimed in the popular press". This enacting of relationships through tweets makes "microblog- 
ging [...] an ongoing performance of identity" (Zappavigna 2012: 38). For Zappavigna (2012: 38), these processes of identity construction are connected with the broader aim of connecting with others, or our "human desire for affiliation". Since we "exist within communities of other voices with which we wish to connect" our tweeting practices become bound to, and relative to the community and its practices of "meaning-making" (Zappavigna 2012: 38).

It is important to stress that Twitter is not a practice that functions in isolation. As mentioned in the quote above, tweets connect to different actions and activities and tap into other meaningful repertoires. In her work, Zappavigna (2012) utilises a corpus of over 7 million tweets (and sub-corpora thereof). Her methodology draws on systemic functional analysis and corpus linguistic expertise. Throughout her monograph she identifies and discusses practices that are part of identity performance. For example, she explores the rallying function of hashtags, how evaluative stance is embedded, or how the use of humor, memes and slang serve to foreground certain identities. In Zappavigna (2014a: 140) on tweets about coffee, she differentiates between "affiliation (personae aligning into communities of value) and identity (personae enacting particular evaluative dispositions)". She further shows how the hashtag or affiliative stance markers in processes of coupling (from a systemic functional perspective "[ideation: coffee/evaluation: positive appreciation: positive reaction]", 2014a: 148) are used to "align personae around shared values" (Zappavigna 2014a: 156). As a consequence, a community of coffee lovers who use coffee as treat and reward emerges (Zappavigna 2014a: 155). Her study thus shows how "linguistic strategies available to personae [are employed] in electronic discourse for construing community" (Zappavigna 2014a: 156).

In her research monograph on microblogging, Dayter (2016: 215) follows a group of eleven non-professional, yet dedicated and passionate ballet students. Using a corpus of 1000 tweets, she explores their acts of self-disclosure, achieved through "self-praise, implicit positive disclosure, third party complaints and personal narratives". In studying the pragmatic force of the tweets, Dayter (2016) reports that there are contradicting repertoires, an "ego repertoire" and a "member of community repertoire". Whereas the former serves to confirm the speaker's face and contribute to the formation of the "ballet hero image", the latter serves to confirm the "others" face", such that it signals the desire to be accepted "into the community" and the willingness to "award social capital to others" (Dayter 2016: 217). Both repertoires are drawn on by individual tweeters. Next to the fact that the members of her focus group mix strategies individually, another finding is that self-praise was a frequent and accepted practice (i.e. there was no criticism of this practice by other tweeters; Dayter 2016: 215, 217), which contributed to the image of a ballet hero. For example, references to "bloody bunioned feet" demonstrate in-group knowledge and thus serve to distinguish between "proper" dancers as opposed to fans; mentioning physical ailments thus translates into proof of a dedication to ballet (Dayter 216: 134). (For further discussion of Facebook 
and Twitter, please consult Zappavigna, Ch. 8 and Eisenlauer, Ch. 9, this handbook).

\section{Conclusions}

There is neither a unified theory nor singular methodological approach to the study of identity construction in computer-mediated contexts. As shown in the literature review, the field is vibrant and insights from studies cross-fertilize each other. As a consequence, we find a rich interface of different approaches, with scholars drawing on previous research conducted within linguistics, but also other neighbouring disciplines.

In this review, we focused on a number of themes which emerge in research on identity construction in various modes of CMC. Much attention was paid to studies of (im)politeness that have adopted online data as their site for research with scholars approaching identity construction by drawing most explicitly on the notions of face and facework (or relational work/rapport management, etc.). Three particular orientations have been shown to be pursued: (a) to further theory building; (b) to study emic negotiations of norms of conduct in and about CMC; and (c) to explore face-aggravating behavior in addition to face-maintaining and face-enhancing behavior. These also mirror general trends within (im)politeness research. Studies inspired by research on gender have been shown to constitute an equally dominant trend, where scholars have underscored, for example, both the pertinence of gender ideologies about men and women, while also drawing attention to the ways factors beyond sex influence the ways these men and women interact online. To illustrate the importance of the construction of expertise, authenticity and trust, we chose the context of e-health communication, where we addressed some of the textual and multimodal ways interlocutors position self and other when engaging in e-health discourse. Finally, the chapter briefly explored the surfacing of emotions, the creation of in- and out-groups and community building, as well as the intertwining of offline and online acts of positioning.

More research on the study of the construction of identity within different computer-mediated contexts is clearly called for. We also predict that there will be increased attention paid to the relationship between online and offline contexts, and the implications of the blurring of these contexts for online identity practices; as well as to multimodal acts of positioning.

\section{Acknowledgments}

Our heartfelt thanks goes to Aline Bieri, who was instrumental in compiling the literature reading list and chasing up the texts for our perusal. For feedback on this 
chapter, we thank Wolfram Bublitz and Christian Hoffmann. All remaining faults and ommissions are our own.

\section{References}

Angouri, Jo and Theodora Tseliga

2010 'you HAVE NO IDEA WHAT YOU ARE TALKING ABOUT!' From e-disagreement to e-impoliteness in two online fora. Journal of Politeness Research 6(1): $57-82$.

Antaki, Charles and Sue Widdicombe (eds.)

1998 Identities in Talk. London: Sage.

Arendholz, Jenny

2013 (In)Appropriate Online Behavior: A Pragmatic Analysis of Message Board Relations Amsterdam/Philadelphia: Benjamins.

Arendholz, Jenny

2014 "You sound very talented" - Negotiating face in online message boards. In: Kristina Bedijs, Gudrun Held and Christiane Maaß (eds.), Face Work and Social Media, 213-234. Münster: Lit-Verlag.

Arundale, Robert B.

2015 Face constituting theory. In: Karen Tracy (ed.), The International Encyclopedia of Language and Social Interaction, 1-9. Hoboken, NJ: John Wiley and Sons. doi: 10.1002/9781118611463.wbielsi094.

Baker, Paul

2001 Moral panic and alternative identity construction in Usenet. Journal of Computer-Mediated Communication 7(1). doi: 10.1111/j.1083-6101.2001.tb00136.x.

Bamberg, Michael G. W.

1997 Positioning between structure and performance. Journal of Narrative and Life History 7(1-4): 335-342.

Bargiela-Chiappini, Francesca

2006 Face. In: Keith Brown (ed.), Encyclopedia of Language and Linguistics, 421423. Oxford: Elsevier.

Baym, Nancy

1996 Agreements and disagreements in a computer-mediated discussion. Research

Baym, Nancy

on Language and Social Interaction 29(4): 315-345.

1998 The emergence of on-line community. In: Steven G. Jones (ed.), Cybersociety 2.0: Revisiting Computer-Mediated Communication and Community, 35-68. Thousand Oaks, CA: Sage.

Bedijs, Kristina

2014 Shared face and face-enhancing behaviour in social media: Commenting on the Spanish goalkeeper's tears on YouTube. In: Kristina Bedijs, Gudrun Held and Christiane Maßß (eds.), Face Work and Social Media, 136-156. Münster: Lit-Verlag.

Bedijs, Kristina, Gudrun Held and Christiane Maßß (eds.)

2014a Face Work and Social Media. Münster: Lit-Verlag. 
Bedijs, Kristina, Gudrun Held and Christiane Maaß

2014b Introduction: Face work and social media. In: Kristina Bedijs, Gudrun Held and Christiane Maaß (eds.), Face Work and Social Media, 9-28. Münster: Lit-Verlag.

Bolander, Brook

2012 Disagreements and agreements in personal/diary blogs: A closer look at responsiveness. Journal of Pragmatics 44(12): 1607-1622.

Bolander, Brook

2013 Language and Power in Blogs: Interaction, Disagreements and Agreements. Amsterdam/Philadelphia: Benjamins.

Bolander, Brook

2017 Language and identity on Facebook. In: Steven Thorne and Stephen May (eds.), Encylopedia of Language and Education: Language and Technology, 1-13. New York: Springer.

Bolander, Brook and Miriam A. Locher

2010 Constructing identity on Facebook: Report on a pilot study. In: Karen Junod and Didier Maillat (eds.), Performing the Self, 165-185. Tübingen: Narr Francke.

Bolander, Brook and Miriam A. Locher

2014 Doing sociolinguistic research on computer-mediated data: A review of four methodological issues. Discourse, Context and Media 3: 14-26.

Bolander, Brook and Miriam A. Locher

2015 "Peter is a dumb nut": Status updates and reactions to them as 'acts of positioning' in Facebook. Pragmatics 25(1): 99-122.

Bou-Franch, Patricia and Pilar Garcés-Conejos Blitvich

2014 Conflict management in massive polylogues: A case study from YouTube. Journal of Pragmatics 73: 19-36.

boyd, danah $\mathrm{m}$. and Nicole B. Ellison

2007 Social network sites: Definition, history, and scholarship. Journal of Computer-Mediated Communication 13(1): 210-230.

Brown, Penelope and Stephen C. Levinson

1987 Politeness: Some Universals in Language Usage. Cambridge, UK: Cambridge University Press.

Bucholtz, Mary and Kira Hall

2005 Identity and interaction: A sociocultural linguistic approach. Discourse Studies 7(4-5): 585-614.

Bucholtz, Mary and Kira Hall

2008 Finding identity: Theory and data. Multilingua 27(1-2): 151-163.

Bucholtz, Mary and Kira Hall

2010 Locating identity in language. In: Carmen Llamas and Dominic Watt (eds.),

Burke, Kenneth Language and Identities, 18-28. Edinburgh: Edinburgh University Press.

1969 A Rhetoric of Motives. Berkeley, CA: University of California Press.

Chen, Gina Masullo and Zainul Abedin

2014 Exploring differences in how men and women respond to threats to positive face on social media. Computers in Human Behavior 38: 118-126. 
Darics, Erika

2010 Politeness in computer-mediated discourse of a virtual team. Journal of Politeness Research 6(1): 129-150.

Davies, Bronwyn and Rom Harré

1990 Positioning: The discursive production of selves. Journal for the Theory of Social Behaviour 20(1): 43-63.

Dayter, Daria

2014 Self-praise in microblogging. Journal of Pragmatics 61: 91-102.

Dayter, Daria

2016 Discursive Self in Microblogging: Speech Acts, Stories and Self-Praise. Amsterdam/Philadephia: Benjamins.

Dayter, Daria and Sofia Rüdiger

2014 Speak your mind, but watch your mouth: Complaints in CouchSurfing references. In: Kristina Bedijs, Gudrun Held and Christiane Maaß (eds.), Face Work and Social Media, 193-212. Münster: Lit-Verlag.

De Fina, Anna

2010 The negotiation of identities. In: Miriam A. Locher and Sage L. Graham (eds.), Interpersonal Pragmatics, 205-224. Berlin/Boston: de Gruyter.

Deppermann, Arnulf

2013 How to get a grip on identities-in-interaction: (What) does 'positioning' offer more than 'membership categorization'? Evidence from a mock story. Narrative Inquiry 23(1): 62-88.

DuVal Smith, Anna

1999 Problems of conflict management in virtual communities. In: Marc Smith and Peter Kollock (eds.), Communities in Cyberspace, 134-163. New York: Routledge.

Dynel, Marta

2015 The landscape of impoliteness research. Journal of Politeness Research 11(2): 329-354.

Eckert, Penelope

1989 Jocks and Burnouts: Social Categories and Identity in the High School. New York: Teachers College Press.

Ehrhardt, Claus

2014 Politeness and face work in German forum communication. In: Kristina Bedijs, Gudrun Held and Christiane Maßß (eds.), Face Work and Social Media, 84-107. Münster: Lit-Verlag.

Eisenchlas, Susana A.

2012 Gendered discursive practices on-line. Journal of Pragmatics 44(4): 335-345. Eisenlauer, Volker

2013 A Critical Hypertext Analysis of Social Media. The True Colours of Facebook. London/New York: Continuum.

Fitzgerald, Richard

2015 Membership categorization analysis. In: Karen Tracy (ed.), The International Encyclopedia of Language and Social Interaction, 1-11. Hoboken, NJ: John Wiley and Sons. doi: 10.1002/9781118611463.wbielsi018.

Fröhlich, Uta

2014 Reflections on the psychological terms self and identity in relation to the concept of face for the analysis of online forum communication. In: Kris- 
tina Bedijs, Gudrun Held and Christiane Maaß (eds.), Face Work and Social Media, 110-132. Münster: Lit-Verlag.

Gal, Susan

1992 Dialect variation and language ideology. Paper presented at the $91^{\text {st }}$ Annual Meeting of the American Anthropology Association, San Francisco, CA.

Georgakopoulou, Alexandra

2013 Small stories and identities analysis as a framework for the study of im/politeness-in-interaction. Journal of Politeness Research 9(1): 55-74.

Goffman, Erving

1955 On face work: An analysis of ritual elements in social interaction. Psychiatry 18(3): 213-231.

Goffman, Erving

1959 The Presentation of Self in Everyday Life. New York: Doubleday Anchor Books.

Goffman, Erving (ed.)

1967 Interaction Ritual: Essays on Face-to-Face Behavior. Garden City, NY: Anchor Books.

Goffman, Erving

1974 Frame Analysis: An Essay on the Organization of Experience. Cambridge, MA: Harvard University Press.

Graham, Sage Lambert

2007 Disagreeing to agree: Conflict, (im)politeness and identity in a computer-mediated community. Journal of Pragmatics 39(4): 742-759.

Graham, Sage Lambert

2008 A manual for (im)politeness?: The impact of the FAQ in electronic communities of practice. In: Derek Bousfield and Miriam A. Locher (eds.), Impoliteness in Language: Studies on Its Interplay with Power in Theory and Practice, 281-304. Berlin/Boston: de Gruyter.

Hall, Kira and Mary Bucholtz

2013 Epilogue: Facing identity. Journal of Politeness Research 9(1): 123-132.

Hampel, Elisabeth

2015 "Mama Zimbi, pls help me!" - Gender differences in (im)politeness in Ghanaian English advice-giving on Facebook. Journal of Politeness Research 11(1): 99-130.

Hardaker, Claire

2010 Trolling in asynchronous computer-mediated communication: From user discussions to academic definitions. Journal of Politeness Research 6(2): 215-242.

Hardaker, Claire and Sage L. Graham

2017 Impoliteness and computer-mediated communication. In: Jonathan Culpeper, Michael Haugh and Dániel Kádár (eds.), Handbook of Linguistic (Im)Politeness, t.b.a. London: Palgrave.

Harrison, Sandra and Julie Barlow

2009 Politeness strategies and advice-giving in an online arthritis workshop. Journal of Politeness Research 5(1): 93-111.

Harvey, Kevin and Nelya Koteyko

2013 Exploring Health Communication: Language in Action. London: Routledge.

Haugh, Michael

2010 When is an email really offensive?: Argumentativity and variability in evaluations of impoliteness. Journal of Politeness Research 6(1): 7-31. 
Haugh, Michael and Wei-Lin Melody Chang

2015 Troubles talk, (dis)affiliation and the participation order in Taiwanese-Chinese online discussion boards. In: Marta Dynel and Jan Chovanec (eds.), Participation in Public and Social Media Interactions, 99-133. Amsterdam/Philadephia: Benjamins.

Haugh, Michael, Wei-Lin Melody Chang and Dániel Z. Kádár

2015 "Doing deference": Identities and relational practices in Chinese online discussion boards. Pragmatics 25(1): 73-97.

Held, Gudrun

2014 Figura ... or face? Reflections on two sociopragmatic key concepts in the light of a recent media conflict between Italians and Germans and its negotiation in Italian internet forums. In: Kristina Bedijs, Gudrun Held and Christiane Maaß (eds.), Face Work and Social Media, 32-81. Münster: Lit-Verlag.

Helfrich, Uta

2014 Face work and flaming in social media. In: Kristina Bedijs, Gudrun Held and Christiane Maaß (eds.), Face Work and Social Media, 297-318. Münster: Lit-Verlag.

Herring, Susan C.

1994 Politeness in computer culture: Why women thank and men flame. In: Mary Bucholtz, A.C. Liang, Laurel A. Sutton and Caitlin Hines (eds.), Cultural Performances: Proceedings of the Third Berkeley Women and Language Conference, 278-294. Berkely, CA: Berkeley Women and Language Group.

Herring, Susan C.

1996 Two variants of an electronic message schema. In: Susan C. Herring (ed.), Computer-Mediated Communication: Linguistic, Social, and Cross-Cultural Perspectives, 81-106. Amsterdam/Philadephia: Benjamins.

Herring, Susan C.

1999 The rhetorical dynamics of gender harassment on-line. The Information Society $15(3): 151-167$.

Herring, Susan C.

2003 Gender and power in on-line communication. In: Janet Holmes and Miriam Meyerhoff (eds.), The Handbook of Language and Gender, 202-228. Malden, MA: Blackwell.

Herring, Susan C.

2013 Discourse in Web 2.0: Familiar, reconfigured, and emergent. In: Deborah Tannen and Anna M. Trester (eds.), Georgetown University Round Table on Languages and Linguistics 2011: Discourse 2.0: Language and New Media, 1-25. Washington, DC: Georgetown University Press.

Herring, Susan C. and John C. Paolillo

2006 Gender and genre variation in weblogs. Journal of Sociolinguistics 10(4): 439-459.

Herring, Susan C. and Sharon Stoerger

2014 Gender and (a)nonymity in computer-mediated communication. In: Susan Ehrlich, Miriam Meyerhoff and Janet Holmes (eds.), The Handbook of Language, Gender and Sexuality, 567-586. Chichester, UK: Wiley-Blackwell.

Hester, Stephen and Peter Eglin

1997 Culture in Action: Studies in Membership Categorisation Analysis. Washington, DC: University Press of America. 
Hössjer, Amelie

2013 Small talk, politeness, and email communication in the workplace. In: Susan C. Herring, Dieter Stein and Tuija Virtanen (eds.), Pragmatics of ComputerMediated Communication, 613-638. Berlin/Boston: de Gruyter.

Hunt, Daniel and Nelya Koteyko

2015 "What was your blood sugar reading this morning?": Representing diabetes self-management on Facebook. Discourse and Society 26(4): 445-463.

Irvine, Judith T.

2001 'Style' as distinctiveness: The culture and ideology of linguistic differentiation. In: Penelope Eckert and John R. Rickford (eds.), Style and Sociolinguis-

Joseph, John Earl tic Variation, 21-43. Cambridge, UK: Cambridge University Press.

2004 Language and Identity: National, Ethnic, Religious. Basingstoke, UK: Palgrave Macmillan.

Joseph, John Earl

2010 Identity. In: Carmen Llamas and Dominic Watt (eds.), Language and Identities, 9-17. Edinburgh: Edingburgh University Press.

Jucker, Andreas H. and Christa Dürscheid

2012 The linguistics of keyboard-to-screen communication: A new terminological framework. Linguistik Online 56(6): 39-64.

Jucker, Andreas H. and Daniela Landert

2011 Private and public in mass media communication: From letters to the editor to online commentaries. Journal of Pragmatics 43(5): 1422-1434.

Kiesling, Scott

2006 Identity in sociocultural anthropology and language. In: Keith Brown (ed.), Encyclopedia of Language and Linguistics, $2^{\text {nd }}$ ed., 495-502. Oxford: Elsevier.

Kleinke, Sonja and Birte Bös

2015 Intergroup rudeness and the metapragmatics of its negotiation in online discussion fora. Pragmatics 25(1): 47-71.

Kluge, Bettina

2014 The collaborative construction of an outsider as a troll in the blogosphere of Latin American immigrants to Quebec, Canada. In: Kristina Bedijs, Gudrun Held and Christiane Maßß (eds.), Face Work and Social Media, 323-348. Münster: Lit-Verlag.

Knupsky, Aimee C. and Natalie M. Nagy-Bell

2011 Dear professor: The influence of recipient sex and status on personalization and politeness in e-mail. Journal of Language and Social Psychology 30(1): $103-113$.

Koteyko, Nelya and Daniel Hunt

2016 Performing health identities on social media: An online observation of Facebook profiles. Discourse, Context and Media 12: 59-67.

Kouper, Inna

2010 The pragmatics of peer advice in a LiveJournal community.Language@Internet 7. http://www.languageatinternet.org/articles/2010/2464.

Kreß, Beatrix

2014 "Hofnarr" and "Bürgerschreck" vs. "kamir-batir" and "barakobamas": Face work strategies and stylising in Russian and German online discussion forums. 
In: Kristina Bedijs, Gudrun Held and Christiane Maaß (eds.), Face Work and Social Media, 442-461. Münster: Lit-Verlag.

Kunkel, Melanie

2014 Impoliteness in the negotiation of expert status: Folk linguistic debates in a French online forum. In: Kristina Bedijs, Gudrun Held and Christiane Maaß Labov, William (eds.), Face Work and Social Media, 403-421. Münster: Lit-Verlag.

1972 Sociolinguistic Patterns. Philadelphia, PA: University of Pennsylvania Press. Landert, Daniela

2014 Personalisation in Mass Media Communication: British Online News between Public and Private. Amsterdam/Philadephia: Benjamins.

Lange, Patricia G.

2014 Commenting on YouTube rants: Perceptions of inappropriateness or civic engagement? Journal of Pragmatics 73: 53-65.

Langlotz, Andreas and Miriam A. Locher

2012 Ways of communicating emotional stance in online disagreements. Journal of Pragmatics 44(12): 1591-1606.

Lee, Carmen

2011 Micro-blogging and status updates on Facebook: Texts and practices. In: Crispin Thurlow and Kristine Mroczek (eds.), Digital Discourse: Language in the New Media, 110-128. Oxford, UK: Oxford University Press.

Léon, Jacqueline

2006 Goffman, Erving (1922-1982). In: Keith Brown (ed.), Encyclopedia of Language and Linguistics, 97-99. Oxford: Elsevier. http://dx.doi.org/10.1016/ B0-08-044854-2/02587-6.

Linnemann, Gesa, Benjamin Brummernhenrich and Regina Jucks

2014 A matter of politeness? On the role of face-threatening acts in online tutoring. In: Kristina Bedijs, Gudrun Held and Christiane Maaß (eds.), Face Work and Social Media, 423-440. Münster: Lit-Verlag.

Locher, Miriam A.

2006 Advice Online: Advice-Giving in an American Internet Health Column. Amsterdam/Philadephia: Benjamins.

Locher, Miriam A.

2008 Relational work, politeness and identity construction. In: Gerd Antos and Eija Ventola (eds.), Handbook of Interpersonal Communication, 509-540. Berlin/ Boston: de Gruyter.

Locher, Miriam A. (ed.)

2010 Politeness and Impoliteness in Computer-Mediated Communication. Special issue, Journal of Politeness Research 6(1).

Locher, Miriam A.

2013a Politeness. In: Carol E. Chapelle (ed.), The Encyclopedia of Applied Linguistics. Oxford: Wiley-Blackwell. doi: 10.1002/9781405198431.wbeal0916.

Locher, Miriam A.

2013b Internet advice. In: Susan Herring, Dieter Stein and Tuija Virtanen (eds.), Pragmatics of Computer-Mediated Communication, 339-362. Berlin/Boston: de Gruyter. 
Locher, Miriam A.

2014 Electronic discourse. In: Klaus P. Schneider and Anne Barron (eds.), Pragmatics of Discourse, 555-581. Berlin/Boston: de Gruyter.

Locher, Miriam A. and Brook Bolander

2014 Relational work and the display of multilingualism in two Facebook groups. In: Kristina Bedijs, Gudrun Held and Christiane Maßß (eds.), Face Work and Social Media, 157-191. Münster: Lit-Verlag.

Locher, Miriam A. and Brook Bolander

2015 Humour in microblogging: Exploiting linguistic humour strategies for identity construction in two Facebook groups. In: Marta Dynel and Jan Chovanec (eds.), Participation in Public and Social Media Interactions, 135-155. Amsterdam/Philadephia: Benjamins.

Locher, Miriam A., Brook Bolander and Nicole Höhn (eds.)

2015 Relational Work in Facebook and Discussion Boards/Fora. Special issue, Pragmatics 25(1).

Locher, Miriam A. and Sage L. Graham

2010 Introduction to interpersonal pragmatics. In: Miriam A. Locher and Sage Lambert Graham (eds.), Interpersonal Pragmatics, 1-13. Berlin/Boston: de Gruyter.

Locher, Miriam A. and Sebastian Hoffmann

2006 The emergence of the identity of a fictional expert advice-giver in an American Internet advice column. Text and Talk 26(1): 69-106. doi: 10.1515/ TEXT.2006.004.

Locher, Miriam A. and Andreas H. Jucker (eds.)

2017 Pragmatics of Fiction. Berlin/Boston: de Gruyter.

Locher, Miriam A. and Stephanie Schnurr

2017 (Im)politeness in health settings. In: Jonathan Culpeper, Michael Haugh and Dániel Kádár (eds.), Palgrave Handbook of Linguistic (Im)Politeness, 689711. London: Palgrave.

Locher, Miriam A. and Richard J. Watts

2005 Politeness theory and relational work. Journal of Politeness Research 1(1): 9-33.

Luzón, María José

2013 "This is an erroneous argument": Conflict in academic blog discussions. Discourse, Context and Media 2(2): 111-119. doi: 10.1016/j.dcm.2013.04.005.

Maaß, Christiane

2014 On the markedness of communication on online message boards as part of a perception-oriented politeness approach. In: Kristina Bedijs, Gudrun Held and Christiane Maaß (eds.), Face Work and Social Media, 238-275. Münster: Lit-Verlag.

Maíz-Arévalo, Carmen

2013 "Just click 'Like"': Computer-mediated responses to Spanish compliments. Journal of Pragmatics 51: 47-67. doi: 10.1016/j.pragma.2013.03.003.

Maíz-Arévalo, Carmen and Antonio García-Gómez

2013 'You look terrific!' Social evaluation and relationships in online compliments.

Discourse Studies 15(6): 735-760. doi: 10.1177/1461445613490011.

Mak, Bernie Chun Nam and Hin Leung Chui

2014 Impoliteness in Facebook status updates: Strategic talk among colleagues 'out- 
side' the workplace. Text and Talk 34(2): 165-185. doi: 10.1515/text-20130042.

Mendoza-Denton, Norma

2002 Language and identity. In: J. K. Chambers, Peter Trudgill and Natalie SchillingEstes (eds.), Handbook of Language Variation and Change, 475-499. Oxford, UK: Blackwell.

Mendoza-Denton, Norma

2008 Homegirls: Language and Cultural Practice among Latina Youth Gangs. Malden, MA: Blackwell.

Meyerhoff, Miriam

2006 Prestige, overt and covert. In: Keith Brown (ed.), Encyclopedia of Language and Linguistics, $2^{\text {nd }}$ ed., 77-79. Oxford, UK: Elsevier.

Morrow, Phillip R.

2006 Telling about problems and giving advice in an Internet discussion forum: Some discourse features. Discourse Studies 8(4): 531-548.

Morrow, Phillip R.

2012 Online advice in Japanese: Giving advice in an Internet discussion forum. In: Holger Limberg and Miriam A. Locher (eds.), Advice in Discourse, 255-279. Amsterdam/Philadephia: Benjamins.

Mullany, Louise

2012 Discourse, gender and professional communication. In: James Paul Gee and Michael Handford (eds.), The Routledge Handbook of Discourse Analysis, 509-522. London: Routledge.

Nastri, Jacqueline, Jorge Peña and Jeffrey Hancock

2006 The construction of away messages: A speech act analysis. Journal of Computer-Mediated Communication 11(4): 1025-1045.

Neurauter-Kessles, Manuela

$2011 \mathrm{Im} /$ polite reader responses on British online news sites. Journal of Politeness Research 7(2): 187-214.

Neurauter-Kessles, Manuela

2013 Impoliteness in cyberspace: Personally abusive reader responses in online news media. Ph.D. dissertation, University of Zurich. http://opac.nebis.ch/ediss/ 20131752.pdf.

Nishimura, Yukiko

2010 Impoliteness in Japanese BBS interactions: Observations from message exchanges in two online communities. Journal of Politeness Research 6(1): $33-55$.

Ochs, Elinor

1993 Constructing social identity: A language socialization perspective. Research on Language and Social Interaction 26(3): 287-306.

Panyametheekul, Siriporn and Susan C. Herring

2003 Gender and turn allocation in a Thai chat room. Journal of Computer-Mediated Communication 9(1). doi: 10.1111/j.1083-6101.2003.tb00362.x.

Page, Ruth

2012 Stories and Social Media: Identities and Interaction. London: Routledge.

Page, Ruth

2014a Hoaxes, hacking and humour: Analysing impersonated identity on social network sites. In: Philip Seargeant and Caroline Tagg (eds.), The Language of 
Social Media: Identity and Community on the Internet, 46-64. Basingstoke, UK: Palgrave Macmillan.

Page, Ruth

2014b Saying 'sorry': Corporate apologies posted on Twitter. Journal of Pragmatics 62: 30-45. doi: 10.1016/j.pragma.2013.12.003.

Peña, Jorge and Nicholas Brody

2014 Intentions to hide and unfriend Facebook connections based on perceptions of sender attractiveness and status updates. Computers in Human Behavior 31: 143-150. doi: 10.1016/j.chb.2013.10.004.

Perelmutter, Renee

2013 Klassika zhanra: The flamewar as a genre in the Russian blogosphere. Journal of Pragmatics 45(1): 74-89. doi: 10.1016/j.pragma.2012.10.006.

Perelmutter, Renee

2015 Shaming, group face, and identity construction in a Russian virtual community for women. In: Marina Terkourafi and Jonathan Culpeper (eds.), Interdisciplinary Perspectives on Im/politeness, 149-180. Amsterdam/Philadephia: Benjamins.

Placencia, María Elena

2012 Online peer-to-peer advice in Spanish Yahoo!Respuestas. In: Holger Limberg and Miriam A. Locher (eds.), Advice in Discourse, 281-305. Amsterdam/Philadelphia: Benjamins.

Planchenault, Gaëlle

2010 Virtual community and politeness: The use of female markers of identity and solidarity in a transvestites' website. Journal of Politeness Research 6(1): 83-103.

Planchenault, Gaëlle

2015 Voices in the Media: Performing French Linguistic Otherness. London: Bloomsbury Academic.

Reid, Elizabeth

1999 Hierarchy and power: Social control in cyberspace. In: Marc A. Smith and Peter Kollock (eds.), Communities in Cyberspace, 107-133. London: Routledge.

Rentel, Nadine

2014 Linguistic strategies for the realisation of face work in Italian tweets. In: Kristina Bedijs, Gudrun Held and Christiane Maaß (eds.), Face Work and Social Media, 349-372. Münster: Lit-Verlag.

Rudolf von Rohr, Marie-Thérèse

2015 'You will be glad you hung onto this quit': Sharing information and giving support when stopping smoking online. In: Catherine Arnott-Smith and Alla Keselman (eds.), Meeting Health Information Needs Outside of Healthcare: Opportunities and Challenges, 263-290. Waltham, MA: Chandos/Elsevier.

Sacks, Harvey

1992 Lectures on Conversation, Vol. II. Ed. by Gail Jefferson. Oxford: Blackwell.

Schrader-Kniffki, Martina

2014 Subject emergence, self-presentation, and epistemic struggle in French language forums. In: Kristina Bedijs, Gudrun Held and Christiane Maßß (eds.), Face Work and Social Media, 376-401. Münster: Lit-Verlag. 
Shum, Winnie and Cynthia Lee

2013 (Im)politeness and disagreement in two Hong Kong Internet discussion forums. Journal of Pragmatics 50(1): 52-83. doi: 10.1016/j.pragma.2013.01.010.

Sillence, Elizabeth

2010 Seeking out very like minded others; exploring trust and advice issues in an online health support group. International Journal of Web Based Communities 6(4): 376-394.

Sillence, Elizabeth

2013 Giving and receiving peer advice in an online breast cancer support group. Cyberpsychology, Behavior, andSocialNetworking 16(6):480-485.doi:10.1089/ cyber.2013.1512.

Skovholt, Karianne, Anette Gronning and Anne Kankaanranta

2014 The communicative functions of emoticons in workplace e-mails: :-). Journal of Computer-Mediated Communication 19(4): 780-797. doi: 10.1111/jcc4.12063.

Spencer-Oatey, Helen

2007 Theories of identity and the analysis of face. Journal of Pragmatics 39(4): 639-656.

Spilioti, Tereza

2011 Beyond genre: Closings and relational work in text-messaging. In: Crispin Thurlow and Kristine Mroczek (eds.), Digital Discourse: Language in the New Media, 67-85. Oxford: Oxford University Press.

Steiner, Peter

1993, July 5 On the Internet, nobody knows you're a dog. The New Yorker [Cartoon].

Sundén, Jenny

2003 Material Virtualities: Approaching Online Textual Embodiment. New York: Peter Lang.

Sunderland, Jane and Lia Litosseliti

2002 Gender identity and discourse analysis: Theoretical and empirical considerations. In: Lia Litosseliti and Jane Sunderland (eds.), Gender Identity and Discourse Analysis, 1-39. Amsterdam/Philadephia: Benjamins.

Swann, Joan

2002 Yes, but is it gender? In: Lia Litosseliti and Jane Sunderland (eds.), Gender Identity and Discourse Analysis, 43-67. Amsterdam/Philadelphia: Benjamins.

Thaler, Verena

2014 Negative evaluation and face work in French and Italian online comments.

In: Kristina Bedijs, Gudrun Held and Christiane Maaß (eds.), Face Work and Social Media, 277-296. Münster: Lit-Verlag.

Theodoropoulou, Irene

2015 Politeness on Facebook: The case of Greek birthday wishes. Pragmatics 25(1): 23-45.

Thurlow, Crispin

2001 Talkin' 'bout my communication: Communication awareness in early adolescence. Language Awareness 10(2-3): 213-231.

Thurlow, Crispin and Kristine Mroczek

2011 Introduction: Fresh perpespectives on new media sociolinguistics. In: Crispin Thurlow and Kristine Mroczek (eds.), Digital Discourse: Language in the New Media, xix-xliv. Oxford: Oxford University Press. 
Thurlow, Crispin and Michele Poff

2013 Text messaging. In: Susan Herring, Dieter Stein and Tuija Virtanen (eds.), Pragmatics of Computer-Mediated Communication, 163-189. Berlin/Boston: de Gruyter.

Thurnherr, Franziska, Marie-Thérèse Rudolf von Rohr and Miriam A. Locher

2016 The functions of narrative passages in three written online health contexts. In: Daria Dayter and Susanne Mühleisen (eds.), Personal Narrative Online. Special issue, Open Linguistics 2(2).

Turnage, Anna

2007 Email flaming behaviours and organizational conflict. Journal of Computer-Mediated Communication 13(1): 43-59.

Upadhyay, Shiv R.

2010 Identity and impoliteness in computer-mediated reader responses. Journal of Politeness Research 6(1): 105-127.

Vandergriff, Ilona

2013 Emotive communication online: A contextual analysis of computer-mediated communication (CMC) cues. Journal of Pragmatics 51: 1-12. doi: 10.1016/j. pragma.2013.02.008.

van Compernolle, Rémi A., Lawrence Williams and Claire McCourt

2011 A corpus-driven study of second-person pronoun variation in L2 French synchronous computer-mediated communication. Intercultural Pragmatics 8(1): 67-91. doi: 10.1515/iprg.2011.003.

Watzlawick, Paul, Janet Helmick Beavin and Don D. Jackson

1967 Pragmatics of Human Communication: A Study of Interactional Patterns, Pathologies and Paradoxes. New York: Norton.

Willems, Herbert

2001 Goffman, Ervin (1921-82). In: Paul B. Baltes (ed.), International Encyclopedia of the Social and Behavioral Sciences, 6297-6301. Oxford: Pergamon.

Yus, Francisco

2011 Cyberpragmatics: Internet-Mediated Communication in Context. Amsterdam/ Philadelphia: Benjamins.

Zappavigna, Michele

2012 Discourse of Twitter and Social Media: How We Use Language to Create Affiliation on the Web. London: Continuum.

Zappavigna, Michele

2014a CoffeeTweets: Bonding around the bean of Twitter. In: Philip Seargeant and Caroline Tagg (eds.), The Language of Social Media: Identity and Community on the Internet, 139-160. Basingstoke: Palgrave Macmillan.

Zappavigna, Michele

2014b Enacting identity in microblogging through ambient affiliation. Discourse and Communication 8(2): 209-228. doi: 10.1177/1750481313510816.

Zhang, Wei and Cheris Kramarae

2014 "SlutWalk" on connected screens: Multiple framings of a social media discussion. Journal of Pragmatics 73: 66-81. doi: 10.1016/j.pragma.2014.07.008.

Zhao, Shanyang, Sherri Grasmuck and Jason Martin

2008 Identity construction on Facebook: Digital empowerment in anchored relationships. Computers in Human Behavior 24(5): 1816-1836. 